\title{
Experimental study on seismic behavior of full scale square concrete filled steel tubular stocky columns
}

\author{
Jin $\operatorname{Liu}^{1, *}$, Liang $\operatorname{Jian}^{1}$, Du Xiuli ${ }^{1}$ \\ ${ }^{1}$ Key Laboratory of Urban Security and Disaster Engineering of Ministry of Education, Beijing University of Technology, Beijing, China
}

\begin{abstract}
This study mainly presented a pseudo-static experiment on two full-scale square CFST short columns with the cross-sectional width of $600 \mathrm{~mm}$ under combined constant axial load and cyclic lateral load. The seismic performance of the two full-scale CFST columns were investigated. Meanwhile, the plastic hinge length of the specimens was discussed. The test results presented that the specimens suffered bend-shear failure. The local buckling of steel tube occurred at the end of the specimens and the core concrete crushed. The safety redundancy of lateral bearing capacity decreased in full-scale specimen. By the method of physical observation, the plastic hinge length $L_{\mathrm{p} 1}$ was determined mainly according to the range of the local buckling of steel tube. There had a great difference between the prediction of plastic hinge lengths by the existing calculation model and the plastic hinge lengths obtained by the test.
\end{abstract}

\section{Introduction}

Concrete filled steel tubular (CFST) columns have been increasingly adopted in bridges and high-rise buildings in high intensity earthquake areas due to high strength, convenient construction, and excellent anti-seismic performance [1-6]. Because of the high axial load and the large size of the columns, there was a large number of square CFST stocky columns in many high rise buildings. The stocky columns have a high stiffness, so they are subjected to large lateral loads at small lateral displacements, causing brittle shear failure [7-9]. Hence, the seismic behavior of square CFST stocky is increasingly becoming a critical problem in the engineering field. Pseudo-static tests are usually adopted to investigate the seismic behavior of CFST columns, that is, a constant axial load and lateral cyclic load are applied to columns simultaneously [10]. Experimental studies on square CFST columns under a combination of axial load and cyclic lateral loads have been conducted by many researches [11-15]. Furthermore, it has been proved that the seismic behavior of reinforcement concrete columns was affected with the different section dimension [16-17]. Therefore, the seismic performance of square CFST stocky columns may be different in the large section dimension. Meanwhile, current codes for CFST columns
[18-21] were all based on the experimental results obtained from small dimension CFST columns. Hence, it was necessary to test the full-scale CFST stocky columns. Under the earth quake, a large plastic deformation usually occurred at the end of the columns in structures, which may develop to be the plastic hinge [22]. Especially, the above research findings are mainly on $L_{\mathrm{p}}$ of reinforced concrete columns or beams, whereas very few research results on $L_{\mathrm{p}}$ of CFST columns were found.

Based on the above research, it is necessary to study the seismic behavior and plastic hinge length of full-scale square columns stocky columns. An experimental test of two full-scale square CFST stocky columns was conducted to subject to seismic behavior and plastic hinge length. Seismic performances of the columns were discussed in detail.

\section{Experiment program}

\subsection{Specimen design}

In this study, two full-scale square CFST stocky columns with the section dimension in $600 \mathrm{~mm}$ were designed to investigate seismic behavior. The width to thickness ratio $B / t$ of two specimens was 50 that satisfied the require of the current codes. The axial load ratio $(n)$ was taken as 0.4. The details of two specimens are shown in Fig. 1. 


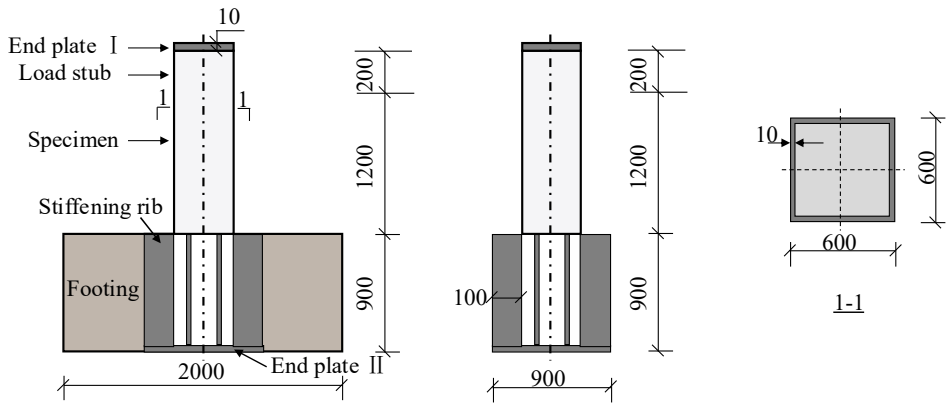

Figure 1. Details of test specimens (Units: $\mathrm{mm}$ ).

\subsection{Material properties}

Three tensile coupons were tested and the yield strength of steel was measured as $336.5 \mathrm{MPa}$. In addition, commercial concrete with the same batch was adopted to fabricate the specimen. The average compressive strength and the splitting tensile strength was measured as 58.5 $\mathrm{MPa}$ and $4.93 \mathrm{MPa}$, respectively.

\subsection{Test setup, instrumentation and test procedures}

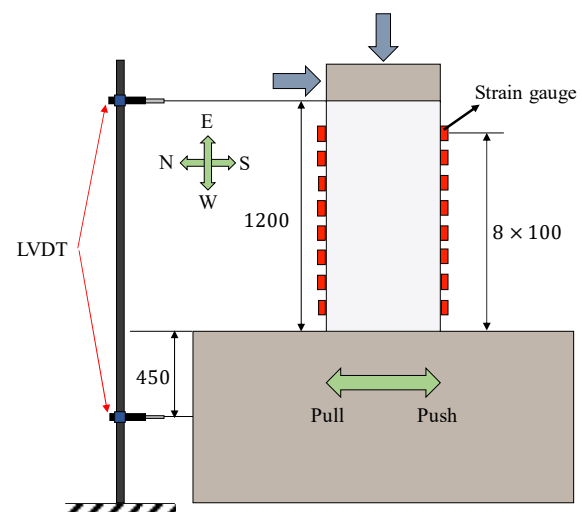

Figure 2. Instrumentation diagram.

\section{Experimental results}

\subsection{Failure modes}

The failure process and failure mode of the two specimens were similar shown as Fig. 4. The local buckling of steel tube occurred at the bottom of the column, where plastic deformation of the specimens concentrated. The hoop
Two full scale square CFST stocky columns were investigated experimentally in the Key Laboratory of urban security and Disaster Engineering of the Education Ministry at the Beijing University of Technology, China. As shown in Fig. 2, two linear variable displacement transducers (LVDTs) and sixteen strain gauges were set up to monitor the displacement and strain on the steel tube. As shown in Fig. 3, the cyclic lateral load was applied by controlling the lateral displacement. When the lateral load had deteriorated below $85 \%$ of the maximum measured lateral load capacity, the test ended [10-11].

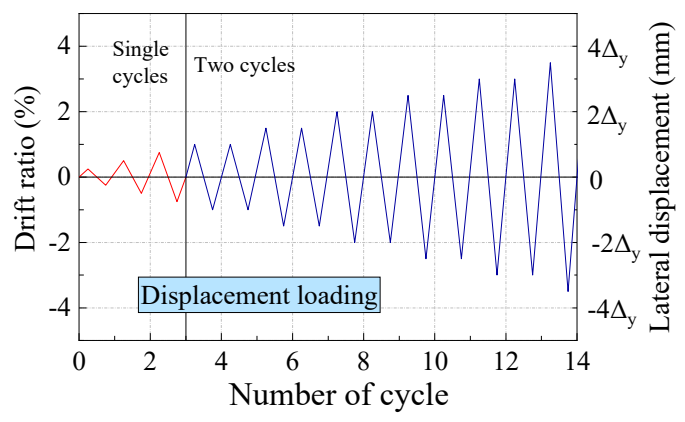

Figure 3. Cyclic loading protocol.

stress of steel tube increased for restraining core concrete lateral deformation, and the steel tube took large axial load due to crushing of core concrete. Core concrete crushed and the yield of steel tube occurred resulting to the attenuation of the shear strength of the specimen. In order to observe the failure mode of the core concrete, the steel tube was peeled off in Fig. 5. The failure range of the core concrete is $300 \mathrm{~mm}$, and the core concrete was severely crushed in the plastic hinge region.

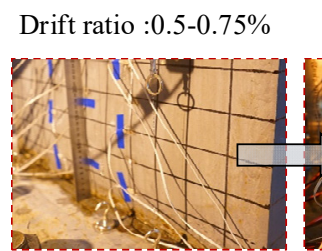

Fristly local buckling
Drift ratio $: 2 \%$

Drift ratio :3\%

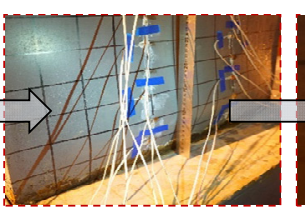

Expanding local buckling
Drift ratio $: 4 \%$

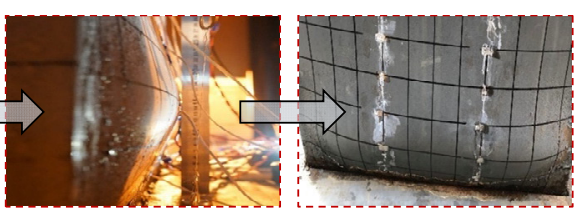

Paint peeling
Bearing capacity decrease

Figure 4. End failure of the columns of CFST-SX-1. 


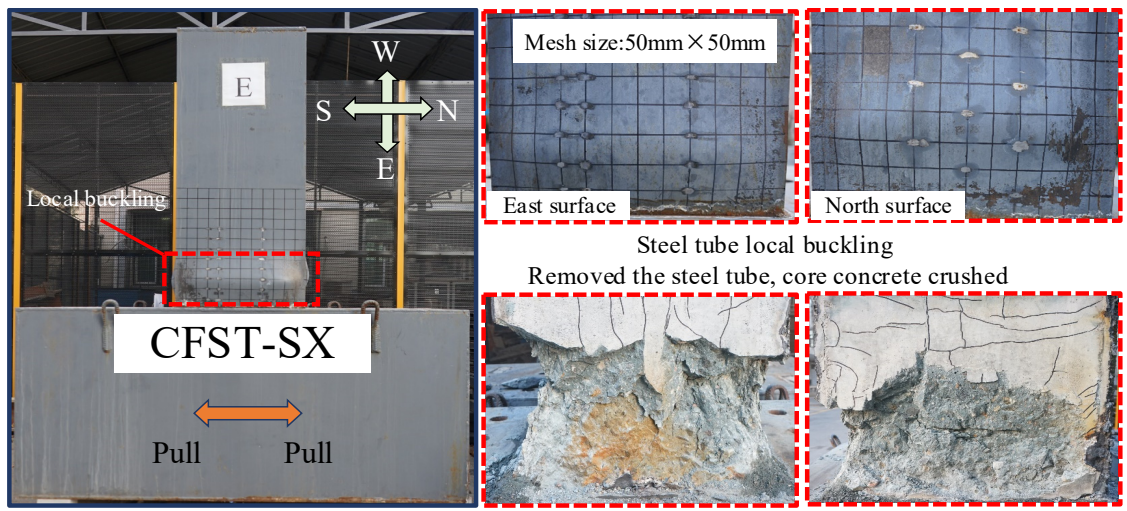

Figure 5. Final failure patterns of the column (CFST-SX-1).

\subsection{Load-displacement hysteretic curves and skeleton curves}

The load-displacement hysteretic curves of test columns were shown in Fig. 6. The hysteretic curves indicated that all of the specimens underwent three stages: the elastic stage, the elasto-plastic stage and failure stage. With the loading progress, the stiffness decreased and energy dissipation increased. The hysteretic loops demonstrated a not strictly symmetric hysteretic behavior for each column. This was caused that the internal defects of the concrete can not be avoided and the internal defects would be prior to develop cumulative damage under lateral cyclic loading. Drift ratio (\%)

(a)

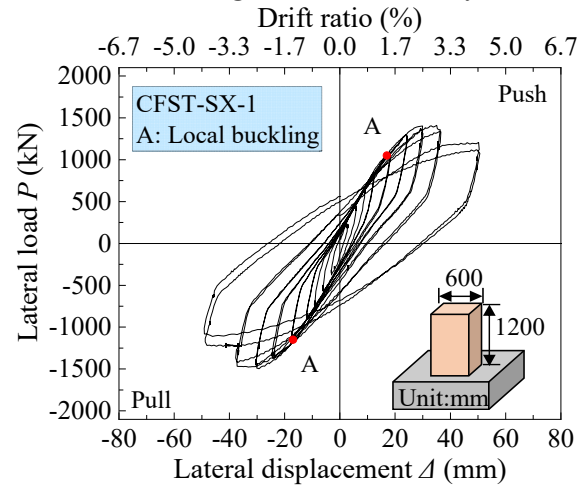

Figure 6. Hysteretic curves of

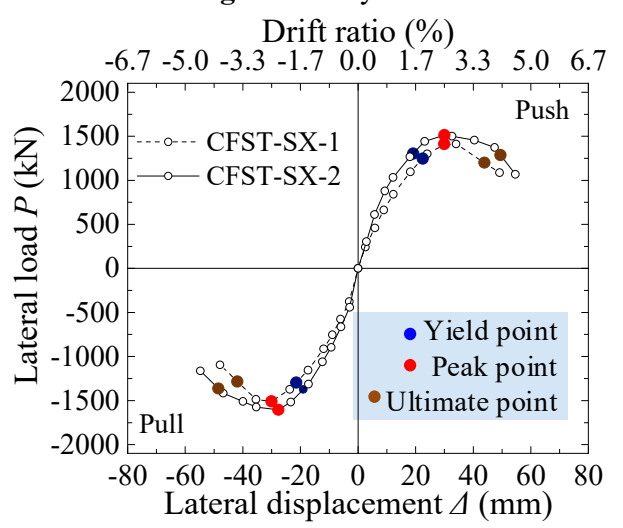

Figure 7. Skeleton curves of the two columns.

\subsection{Ductility, stiffness degradation and energy dissipation}

The skeleton curves of the tested specimens were obtained by connecting the maximum load point at each displacement level according to the load-displacement hysteretic curves, as shown in Fig. 7. The Chinese technical code for CFST structures GB 50936-2014 [21] specifies the requirement on the bearing capacity for CFST structures: the calculated value $\left(V_{m, c}\right)$ of the shear capacity of CFST-SX is $1396.8 \mathrm{kN}$ in combining shear, moment and axial load. The ratio of the test shear value $\left(V_{m, t}\right)$ to the calculated shear value $\left(V_{m, c}\right)$ was used as the evaluation index. As demonstrated in Fig. 8, the safety redundancy of shear bearing capacity is less than $20 \%$ in full-scale specimen.

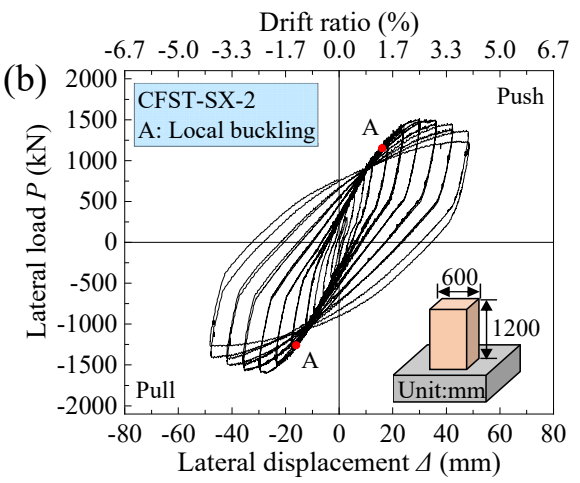

(a) CFST-SX-1; (b) CFST-SX-2.

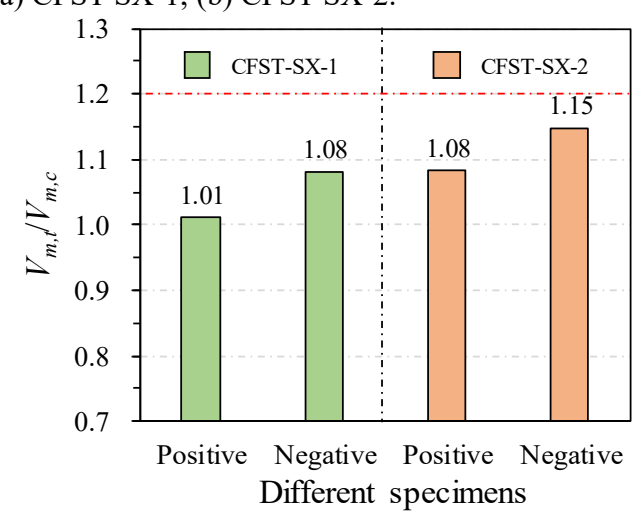

Figure 8. Test shear value/calculated shear value.

For conveniently evaluating the seismic behavior of fullscale square CFST stocky columns, the equivalent elastoplastic energy method was adopted to obtain the 
yield point [10]. In the Chinese technical code [21] for CFST structures, the requirement for the ductility was specified: the limits of the allowable elastic interstory drift angle $\left[\theta_{e}\right]$ and elastoplastic interstory drift angle $\left[\theta_{p}\right]$ are $1 / 300(0.0033 \mathrm{rad})$, and $1 / 50(0.02 \mathrm{rad})$, respectively. For full-scale square CFST stocky columns in this study, the elastic interstory drift angle was 0.017 rad by averaging the two specimens and the elastoplastic interstory drift angle was $0.038 \mathrm{rad}$ by averaging the two specimens. Compared with the elastoplastic interory drift angle of scale CFST columns [22], the rotation capacity of the fullscale CFST columns was slightly smaller.

During cyclic loading, the full-scale square CFST stocky columns presented progressively stiffness degradation. The secant stiffness can be used to define the stiffness of the specimens [23]. Fig. 9 illustrated the relationship between the secant stiffness and drift ratio of each specimen. With the lateral displacement increasing, the secant stiffness exhibited a rapidly degradation. This is because the core concrete crushed and the steel tube

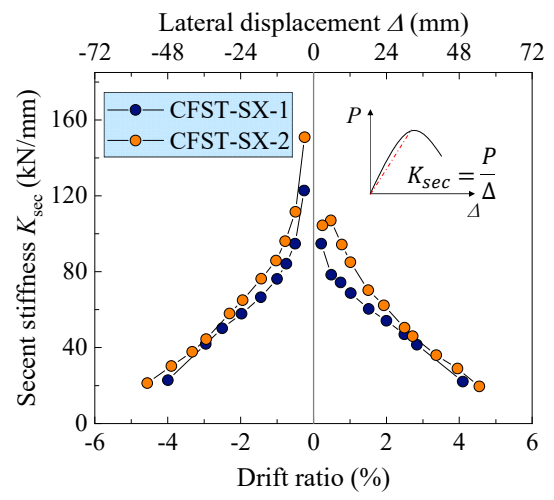

Figure 9. Secant stiffness degradation.

\section{Evaluation of plastic hinge length}

\subsection{Method using measured curvature profiles}

In the study, the columns curvature was calculated from the sum of the strain values between the pair of strain gages located at same height above the footing interface, divided by their horizontal distance. For cantilever

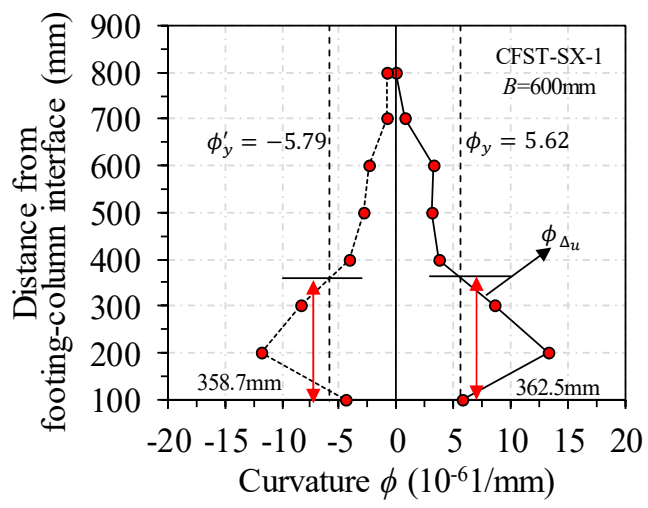

appeared local buckling. For the square CFST columns, the confinement provided by the steel tube was not uniform and the effect of confinement decreased with increase of the section dimension [2].

Under an earthquake, the transformation of mechanical properties for square CFST stocky columns is accompanied with the energy dissipation that determined whether the structure can resist the earthquake motion. In this study, the equivalent viscous damping coefficient $\xi_{e}$ was adopted to evaluate the energy dissipation capacities of the specimens. The equivalent viscous damping coefficients of the two test specimens were calculated for the ever cycle at each drift ratio. Fig. 10 presents the relationship between the equivalent viscous damping coefficient and the drift ratio from yield to failure. When the drift ratio reached approximately $1.5 \%$, the square CFST stocky columns reached the yield point. Accordingly, the specimens presented the small values of equivalent viscous damping coefficients. The equivalent viscous damping coefficients of the specimens increased with the drift ratio increases.

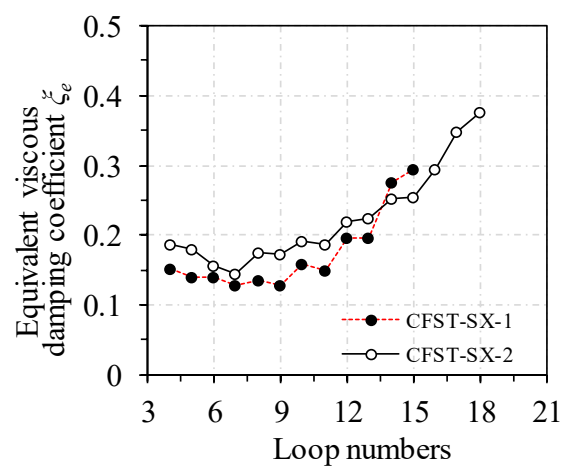

Figure 10. Equivalent viscous damping coefficient.

column specimens, the plastic deformation was mainly concentrated in the plastic hinge region under the lateral cycle load. Therefore, the large and nonlinear curvature occurred in the plastic hinge region after the column yield. On the contrary, the curvature distribution out of the plastic hinge region still kept an approximately straight line after yielding. Fig. 11 presented the plastic hinge length $L_{p 2}$ by measured curvature profiles.

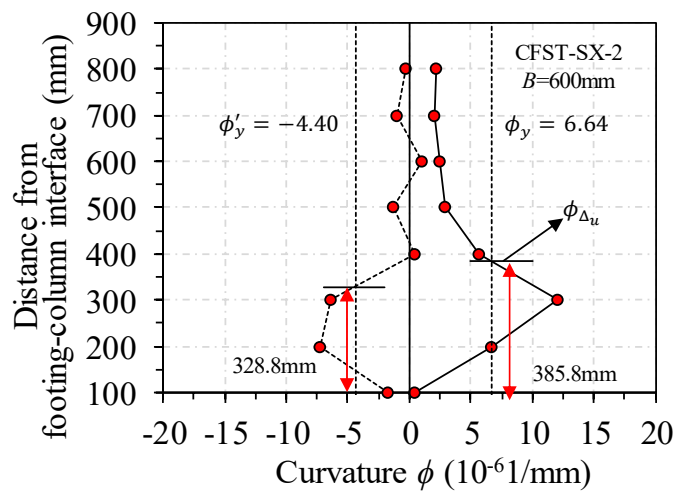

Figure 11. Plastic hinge length evaluation from the measured column curvature profile. 


\subsection{Comparison with other researchers' results}

In Table 1, the plastic hinge lengths obtained by the physical observation and measure curvature profiles are compared with those calculated from formulae or method proposed by other researchers. As show in Table 7, it can be seen that the plastic hinge lengths that were given by various researchers scattered a wide range. Leading to this phenomenon, there was not a clear definition of plastic hinge length in the past studies. In addition, most of researches [21-22] determined the plastic hinge length by using the physical observation, but the method was very subjective. In this study, there had a great difference between the prediction of plastic hinge lengths by the existing calculation model and the plastic hinge lengths obtained by the test. Different from the reinforced concrete columns, the well confinement was provided by the steel tube to the core concrete and the concrete infill delayed the local buckling of the CFST columns. At the same time, the prediction formula of plastic hinge length of CFST column was relatively lacking. As the results, further research was needed about the plastic hinge length of the CFST columns.

\begin{tabular}{|c|c|c|c|c|c|c|c|c|c|}
\hline Spec & Surface & $L_{p 1}$ & $L_{p 2}$ & $\begin{array}{l}\text { Baker } \\
\text { model }\end{array}$ & $\begin{array}{c}\text { Ho } \\
\text { model }\end{array}$ & $\begin{array}{c}\text { Bae } \\
\text { model }\end{array}$ & $\begin{array}{l}\text { Zhu } \\
\text { model }\end{array}$ & $\begin{array}{l}\text { Gao } \\
\text { model }\end{array}$ & $\begin{array}{l}\text { Yang } \\
\text { model }\end{array}$ \\
\hline \multirow[t]{2}{*}{ CFST-SX-1 } & & & 3 & 4 & 9 & 4 & $\overline{94}$ & 100.8 & 690.0 \\
\hline & & 200 & 362.5 & 47 & & & & & \\
\hline \multirow[t]{2}{*}{ CFST-SX-2 } & & 230 & 328.8 & 47 & 96 & 43 & 94 & & 0 \\
\hline & North & 260 & 385.8 & 478.3 & 968.4 & 436.1 & 942.6 & 100.8 & 690.0 \\
\hline
\end{tabular}

\section{Conclusions}

In this study, the seismic performance of two full-scale square CFST stocky columns was investigate with a combination by the constant axial load and the lateral cyclic load. The seismic performances were investigated. Based on the limited experimental results in this study, the following conclusions can be drawn.

(1) The specimens were failed by local buckling of the steel tube and crushing of the core concrete. The safety redundancy of shear bearing capacity decreased with increase of the section dimension

(2) The ductility of the full-scale square CFST stocky column was smaller compared with the scale model test. Therefore, the rotation capacity of square CFST columns decreased with the section dimension increases.

(3) Adopting the two methods to valuate the plastic hinge length, the plastic hinge length $L_{p 1}$ was less than the plastic hinge length $L_{p 2}$. In addition, the calculate models of plastic hinge length, that was proposed by the previous studies, can not well predict the plastic hinge length for the CFST column.

\section{Acknowledgements}

This work was supported by the National Natural Science Foundation of China (No. 51822801) and the National Key Basic Research and Development Program of China (No. 2018YFC1504302). The support is gratefully appreciated.

\section{References}

1. Chang X, Huang C K and Chen Y J 2009. mechanical performance of eccentrically loaded pre-stressing concrete filled circular steel tube columns by the mean of expansive cement. Eng. Struct.31 11 258897.
2. Wang Y Y, Chen P, Liu C Y and Zhang Y 2017 size effect of circular concrete-filled steel tubular short columns subjected to axial compression. Thin-walled. Struct. 120 397-407.

3. Du Y S, Chen Z H and Xiong M X 2016 experimental behavior and design method of rectangular concretefilled tubular columns using Q460 high-strength steel. Constr. Build. Mater. 12530 856-72.

4. Qu X S, Chen Z H and Sun G J 2015 axial behavior of rectangular concrete-filled cold-formed steel tubular columns with different loading methods. Steel. Compos.18 1 71-90.

5. Hassanein M F and Kharoob O F 2014 compressive strength of circular concrete filled doubles skin tubular short columns. Thin-Walled. Struct. 774 165173.

6. Hassanein M F, Kharoob O F and Garden L 2015 behavior and design of square concrete filled double skin tubular columns with inner circular tubes. Eng. Struct. 10010 410-24.

7. Li Y A, Huang Y T and Hwang S J 2014 seismic response of reinforced concrete short columns failed in shear. ACI. Struct. J. 1114 945-54.

8. Ding M K, Zhang Y X and Li Q Q 2004 shear strengthening of RC short columns with ECC jacket: cyclic behavior tests. Eng. Struct.160 535-45.

9. Ding F X, Luo L, Wang L P, Cheng S S and Yu Z W 2018 pseudo-static tests of terminal stirrup-confined concrete-filled rectangular steel tubular columns. J. Constr. Steel. Res. 14412 135-52.

10. Sakino K and Ishibashi H 1985 experimental study on concrete filled square steel tubular short columns subjected to cyclic shearing force and constant axial force. Tran. Architect. Ins. Jpn. 351 81-89.

11. Han L H, Tao Z and Yao G H 2008 behavior of concrete filled steel tubular members subjected to shear and constant axial compression. Thin-Walled. Struct. 469 765-80. 
12. Han L H, Yang Y F and Tao Z 2003 concrete-filled thin-walled steel SHS and RHS beam-columns subjected to cyclic loading. Thin-Walled. Struct. 419 765-80.

13. Varma H A, Ricles J M, Sause R and Lu L W 2004 seismic behavior and design of high-strength square concrete-filled steel tube beam columns. J. Struct. Eng. 1302 169-79.

14. Lani E, Mukai A, Kai M, Tokinoya H, Fukumoto T and Mori K 2004 behavior of concrete-filled steel tube beam-columns. J. Struct. Eng. 1302 189-202.

15. Lv X L and Lu W D 2000 seismic behavior of concrete-filled rectangular steel tubular columns under cyclic loading. J. Build. Struct. 212 2-27.

16. Yu C Y, Ma H, Xie Y P, Li Z B and Tang Z Y 2018 size effect on the seismic performance of highstrength reinforced concrete columns with different shear span-to-depth ratio. Math. Probl. Eng. 2018 119.

17. Li Z B, Xie Y P, Du X L, Ma H, Guo E W and Zhang Y. experimental study on size effect of seismic behavior for reinforced concrete columns under monotonic horizontal loading. J. Build. Struct. 3412 77-85.

18. European Committee for Standardization (CEN), Design of Composite Steel and Concrete Structures, Part 1-1: General Rules and Rules for Buildings, EN 1994-1-1 Eurocode 4 Brussels, 2004.

19. AIJ (Architectural Institute of Japan). 2008. Recommendations for Design and Construction of Concrete Filled Steel Tubular Structures. Tokyo.

20. AISC. 2016. Specification for structural steel buildings. ANSI/AISE 360. Chicago: AISC.

21. CEN (European Committee for Standardization). 2004. Eurocode 4: Design of Composite Steel and Concrete Structures. Part 1-1: General Rules and Rules for Buildings. EN 1994-1-1. Brussels, Belgium: CEN.

22. Liang L, Ding F X, Wang L P and Liu X M 2021 plastic hinge and seismic structural measures of terminal stirrup-confined rectangular CFT columns under low-cyclic load. J. Build. Eng. 34101908.

23. Jiang C, Wu Y F and Wu G 2014 plastic hinge length of FRP-confined square RC columns. J. Compos. Constr. 18404014003. 